\title{
TATA KELOLA TEKNOLOGI INFORMASI DALAM RANGKA INTEGRASI SISTEM DAN TEKNOLOGI INFORMASI LINTAS ANAK PERUSAHAAN
}

\author{
Vande Leonardo dan Budi Yuwono \\ Program Magister Teknologi Informasi, Fakultas Ilmu Komputer, Universitas Indonesia, Kampus Baru \\ UI Depok, Jawa Barat, 16424, Indonesia \\ E-mail: vande.leonardo@alumni.ui.ac.id
}

\begin{abstract}
Abstrak
Integrasi Teknologi Informasi (TI) lintas unit-unit usaha yang independen adalah suatu usaha yang sarat tantangan, terutama karena standar-standar yang berbeda untuk infrastruktur dan aplikasi TI di masing-masing unit. Untuk memastikan keberhasilannya dibutuhkan mekanisme-mekanisme tata kelola TI untuk meminimasi risiko-risikonya. Dalam penelitian ini, digunakan suatu pendekatan berbasis COBIT (Control Objective for Information and Related Technology) untuk mengidentifikasi mekanisme tata kelola TI yang dibutuhkan oleh PT X, sebuah perusahaan di sektor minyak dan gas bumi, dalam mengintegrasikan TI lintas empat anak perusahaannya yang sebelumnya berdiri sendiri Berdasarkan mekanisme tata kelola yang dibutuhkan dan kondisi tata kelola TI yang sudah berjalan, dapat disimpulkan bahwa proses integrasi TI PT X memiliki peluang yang cukup tinggi untuk berhasil.
\end{abstract}

Kata Kunci: tata kelola TI, integrasi TI

\begin{abstract}
Integration of Information Technology (IT) across independent business units is a business full of challenges, primarily because of different standards for IT infrastructure and IT applications in each unit. To ensure the success of IT integration, it needs IT governance mechanisms to minimize the risks. This research used an approach based on COBIT (Control Objective for Information and Related Technology) to identify the mechanisms of IT governance required by PT X, a company in the oil and gas sector, in integrating IT across four subsidiaries that previously stood alone. Based on the necessary governance mechanisms and the conditions of the IT governance that already run, it can be concluded that the process of IT integration at PT X has a fairly high chance to succeed.
\end{abstract}

Keywords: IT governance, IT integration

\section{Pendahuluan}

Integrasi Sistem Informasi (SI) dan Teknologi Informasi (TI) lintas unit usaha telah menjadi tren di banyak perusahaan. Dari SI/TI yang tersebar di tiap unit usaha secara independen satu sama lain, dimana duplikasi aset TI dan data sangat mungkin terjadi, menjadi SI/TI yang dikelola secara terpusat sebagai layanan umum/bersama. Integrasi SI/TI ini selain meningkatkan efisiensi dalam pengadaan, pengoperasian, dan pengelolaan SI/TI juga memudahkan unit-unit usaha berbagi informasi dalam rangka sinergi lintas unit-unit tersebut.

Untuk meminimalkan risiko kegagalan dalam integrasi SI/TI lintas unit yang independen, perlu perencanaan yang menyeluruh termasuk strategi integrasi dan tata kelolanya. Sebuah perusahaan yang bergerak di bidang minyak dan gas bumi (migas), untuk alasan kerahasiaan kita sebut PT X, menyatukan empat anak perusahaannya untuk meningkatkan struktur permodalan (ekuitas) serta menciptakan sinergi dan efisiensi perusahaan. Dengan adanya penggabungan ini maka terjadi berbagi integrasi, salah satunya adalah integrasi SI/TI. Agar tujuan penyatuan dapat tercapai maka dibutuhkan integrasi SI/TI dengan suatu tata kelola yang mampu merealisasikan manfaat dan memitigasi risiko-risiko pengintegrasian itu.

Penelitian ini mencoba untuk mengidentifikasi mekanisme tata kelola TI kunci yang dapat memastikan keberhasilan integrasi SI/TI lintas anak perusahaan pada PT X. Kesiapan dan kemampuan PT $\mathrm{X}$ untuk menerapkan mekanisme tata kelola TI yang telah diidentifikasi itu kemudian dijadikan dasar untuk menilai peluang keberhasilan proses integrasi SI/TI PT X.

Ruang lingkup penelitian ini dibatasi pada tahapan perencanaan dari program-program kerja 
integrasi SI/TI saja, sedangkan tahapan pelaksanaan, monitoring dan evaluasinya adalah di luar lingkup.

Definisi Tata Kelola TI atau Information Technology (IT) Governance menurut Information Technology Governance Institute (ITGI) adalah: "the responsibility of the board of Directors and executive management. It is an integral part of enterprise governance and consists of the leadership and organizational structures and processes that ensure that the organization's IT sustain and extends the organization's strategy and objectives" [1].

Pentingnya tata kelola TI bagi suatu organisasi, membuahkan kebutuhan akan adanya seperangkat kerangka kerja yang merupakan langkah-langkah terbaik dalam mengelola TI. Para ahli dan akademisi yang tergabung dalam ITGI kemudian menjawab kebutuhan ini dengan menerbitkan suatu kerangka kerja kontrol, yang dinamakan COBIT atau Control Objective for Information and Related Technology [2]. COBIT menjawab kebutuhan akan kerangka kerja tata kelola TI dengan tiga karakteristik utamanya, yaitu:

Berfokus pada bisnis, COBIT diciptakan tidak hanya untuk digunakan oleh kalangan TI, tetapi juga dapat digunakan sebagai panduan yang komprehensif bagi manajemen dan para pemilik proses bisnis. Untuk memenuhi sasaran bisnis perusahaan, maka informasi harus sesuai dengan kriteria bisnis yang dalam COBIT disebut sebagai information requirements. Kriteria informasi yang dimaksud adalah keefektifan (effectiveness), efisiensi (efficiency), kerahasiaan (confidentiality), integritas (integrity), ketersediaan (availability), kepatuhan (compliance), dan keandalan (reliability). Karena bersifat generik, kriteria tersebut dapat diaplikasikan di setiap organisasi [3]. Kriteria ini diterapkan dalam pengelolaan sumber-sumber daya TI yang terdiri dari: aplikasi, informasi, infrastruktur, dan tenaga manusia.

Berorientasi proses, COBIT mendefinisikan aktivitas TI dalam model proses generik ke dalam empat domain, yaitu Plan \& Organise (Perencanaan dan Pengorganisasian), Acquire \& Implement (Pengadaan dan Implementasi), Deliver \& Support (Penyediaan Layanan dan Dukungan Teknis), serta Monitor \& Evaluate (Pemantauan dan Evaluasi). Domain-domain ini sebenarnya adalah pemetaan dari area tanggung jawab TI yaitu, perencanaan (plan), pembuatan (build), pelaksanaan (run), dan pengawasan (monitor). Dari keempat domain ini, COBIT mendefinisikan 34 proses TI yang sifatnya umum. COBIT menyediakan pemetaan yang menunjukkan hubungan antara sasaran TI dan proses-proses TI yang mendukung pencapaian setiap sasaran tersebut. Suatu organisasi tidak perlu menerapkan seluruh proses TI yang ada, tetapi disesuaikan dengan sasaran-sasaran TI organisasi. Pada gilirannya, setiap sasaran TI mendukung pencapaian satu atau lebih sasaran bisnis organisasi. COBIT menyediakan pemetaan antara sasaran bisnis dan sasaran-sasaran TI yang medukung pencapaiannya.

Berbasis control, setiap proses TI yang didefinisikan dalam COBIT dirancang untuk mengontrol aspek tertentu dari pengelolaan TI, tujuan pengontrolan itu didefinisikan sebagai sasaran kontrol (control objective). Kontrol didefinisikan sebagai kebijakan, prosedur praktikpraktik, dan struktur organisasi yang dirancang untuk memberikan jaminan yang beralasan bahwa sasaran bisnis akan tercapai dan kejadian yang tidak diinginkan akan dicegah atau dideteksi dan diperbaiki.

Dikendalikan oleh pengukuran, COBIT membantu perusahaan dalam mengelola prosesproses TI-nya dengan menyediakan: (1) Model kemapanan (maturity model), untuk melakukan benchmark dan identifikasi area peningkatan capability yang dibutuhkan; (2) Ukuran kinerja proses TI, dengan menunjukkan bagaimana proses mencapai tujuan bisnis dan TI, dan dapat digunakan untuk mengukur kinerja proses internal berdasarkan prinsip-prinsip balance scorecard; serta (3) Sasaran aktivitas dalam proses-proses TI.

Model Kemapanan, pengukuran tingkat kemapanan proses-proses TI sering dilakukan untuk membandingkan suatu perusahaan dengan perusahaan lain (benchmarking) atau untuk mengidentifikasi proses-proses yang perlu ditingkatkan kemapanannya. COBIT menyediakan suatu model kemapanan (maturity model) yang diturunkan dari model dari Software Engineering Institute [4] untuk kemapanan capability pengembangan perangkat lunak, yang dikenal sebagai Capability Maturity Model (CMM). Keunggulan dari model maturitas ini adalah relatif mudahnya untuk digunakan oleh manajemen untuk menempatkan dirinya dalam skala dan menyadari hal-hal yang perlu dilakukan untuk meningkatkan kemapanan. Tabel I mendeskripsikan kriteria dari tiap tingkat kemapanan.

\section{Metodologi}

Penelitian ini bersifat kualitatif dengan menggunakan metode studi kasus, dengan alur pikir sebagaimana ditunjukkan pada gambar 1 . Pada tahap awal penelitian, informasi yang digali adalah tentang tujuan bisnis integrasi SI/TI perusahaan. Dari tujuan integrasi SI/TI kemudian dicarikan sasaran pengendalian (control 
objectives) yang relevan berdasarkan COBIT. Setiap sasaran pengendalian memiliki beberapa risk drivers, yaitu risiko-risiko yang dapat dikendalikan dengan penerapan sasaran pengendalian tersebut. Masing-masing perusahaan akan memiliki tingkat kekhawatiran yang berbeda-beda terhadap suatu risiko, sehingga dalam penelitian ini perlu dihasilkan profil yang menggambarkan hal tersebut. Selain itu, setiap proses TI yang merealisasikan suatu sasaran pengendalian juga dapat memiliki tingkat kemapanan. Tingkat kemapanan PT X untuk setiap sasaran pengendalian dinilai berdasarkan kriteria dalam model kemapanan generik. Tujuan utama dari dibuatnya profil risiko dan tingkat kemapanan PT $\mathrm{X}$ adalah untuk menentukan prioritas langkah-langkah yang harus dilakukan oleh PT $\mathrm{X}$ untuk menyesuaikan tingkat kemapanan kontrol-kontrolnya dengan profil risiko yang dimilikinya. Penentuan prioritas ini dilakukan dengan menggunakan kuadran prioritas yang disebut quadrant report. Langkah-langkah yang telah diidentifikasi, selanjutnya dikembalikan ke PT $\mathrm{X}$ untuk mendapatkan masukan tentang faktor-faktor pendukung dan penghambat kesuksesan langkah-langkah tersebut.

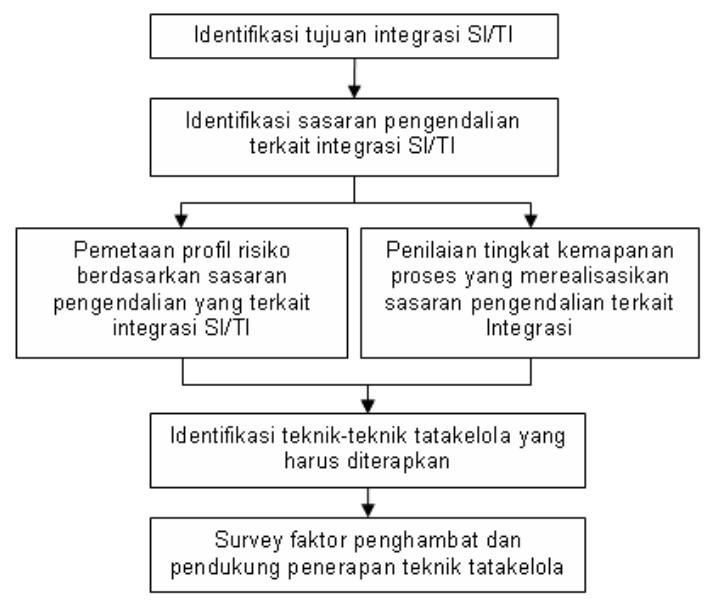

Gambar 1. Alur pikir pencarian solusi.

PT X lahir pada tahun 1969 , dan mengawali kiprahnya sebagai penyedia jasa peralatan komunikasi elektronik, navigasi perkapalan, dan sistem radar angkutan migas. PT $X$ terus berkembang hingga menjadi perusahaan jasa migas terintegrasi yang bergerak di bidang-bidang Geoscience Services (jasa geofisika), Drilling Services (jasa pengeboran migas), dan Oilfield Services (jasa teknologi dan jasa-jasa workover sumur migas).

Pada saat sebelum penyatuan dilakukan, masing-masing anak perusahaan memiliki divisi TI, yang berarti terdapat empat divisi TI termasuk di kantor pusat. Masing-masing divisi ini menerapkan SI/TI yang berbeda-beda. Misalnya, sistem-sistem aplikasi yang digunakan untuk mendukung proses bisnis manajemen proyek dan manajemen SDM bervariasi satu sama lain. Di sisi infrastruktur, masing-masing divisi TI ini memiliki data center dengan perangkat server masing-masing. Karena anak perusahaan memiliki nama domain masing-masing maka sistem $e$-mail yang berjalan pun berbeda. Selain itu, untuk jaringan internet, masing-masing divisi TI memiliki atau menggunakan jasa ISP (Internet Service Provider) yang berbeda-beda.

TABEL I

KRITERIA TINGKAT KEMAPANAN SUATU PROSES TATA KELOLA TI

\begin{tabular}{|c|c|}
\hline Tingkat & Kriteria \\
\hline 0 Non-existent & Proses tidak ada. \\
\hline 1 Ad hoc & $\begin{array}{l}\text { Proses dilakukan berdasarkan inisiatif } \\
\text { perorangan, tanpa adanya suatu standar. }\end{array}$ \\
\hline 2 Repeatable & $\begin{array}{l}\text { Proses dilakukan secara rutin tetapi tidak } \\
\text { ada aturan dan panduan formal. }\end{array}$ \\
\hline 3 Defined & $\begin{array}{l}\text { Proses dilakukan secara rutin sesuai dengan } \\
\text { suatu standar formal tertulis. }\end{array}$ \\
\hline 4 Managed & $\begin{array}{l}\text { Proses dilakukan secara rutin sesuai dengan } \\
\text { suatu standar dan terukur hasilnya. }\end{array}$ \\
\hline 5 Optimized & $\begin{array}{l}\text { Proses dilakukan secara rutin sesuai dengan } \\
\text { suatu standar, terukur hasilnya, dan } \\
\text { senantiasa disempurnakan. }\end{array}$ \\
\hline
\end{tabular}

Setelah perjanjian merger ditandatangani, seluruh divisi TI yang ada kemudian digabung menjadi satu dan bernaung dibawah Departement of Corporate Information System, dan dikepalai oleh seorang Vice President. Departemen ini kemudian terbagi menjadi tiga buah bagian yaitu IT Infrastructures \& Technologies, ERP Development, dan Enterprise Resource Management. Dalam integrasi SI/TI lintas anak perusahaan ini, Departemen TI telah membuat suatu perencanaan TI pasca merger.

\section{Analisis dan Pembahasan}

Pareek [5] menyatakan bahwa integrasi TI harus dikontrol dengan menggunakan prosesproses yang mapan, minimal keberhasilannya dapat diulang (repeatable). Proses-proses ini umumnya berasal dari suatu kerangka kerja tata kelola yang mapan. Lebih lanjut Pareek mengatakan bahwa banyak proses dan sasaran kontrol yang dimiliki oleh COBIT dapat digunakan sebagai kerangka kerja untuk mengendalikan suatu program SI/TI dalam rangka integrasi lintas unit-unit usaha. Namun, dari 34 proses yang dimiliki oleh COBIT, tidak semua 
relevan dengan masalah integrasi SI/TI. Bhatia [6] berpendapat bahwa permasalahan integrasi dapat diidentifikasi lebih baik dengan mengacu pada dasar haluan pada arsitektur informasi dan aplikasi perusahaan. Dalam COBIT, proses yang mengatur tentang arsitektur adalah pada proses PO2: Determine the Information Architecture.

Penyatuan anak-anak perusahaan merupakan suatu kerjasama antara beberapa entitas, sehingga bisa dipastikan adanya suatu tujuan bersama yang ingin dicapai. Tujuan bersama ini bisa diartikan sebagai tujuan bisnis (business goal). COBIT menyediakan daftar kategori business goals yang mungkin dimiliki oleh suatu organisasi [4]. Dalam dokumen Company Profile 2008 PT X disebutkan beberapa hal yang menjadi tujuan penyatuan anak-anak perusahaan, yaitu untuk meningkatkan struktur permodalan (ekuitas) dan untuk menciptakan sinergi dan efisiensi perseroan. Tujuan bisnis ini, dalam kaitannya dengan TI, termasuk dalam kategori penciptaan efisiensi perseroan. Tujuan-tujuan bisnis yang memiliki keterkaitan erat dengan penciptaan efisiensi dapat dipetakan ke tujuan-tujuan TI menurut tabel pemetaan COBIT, sebagaimana terlihat pada tabel II.

TABEL II

TUJUAN BISNIS (BUSINESS GOALS) YANG RELEVAN DENGAN TUJUAN MERGER DI PT X SERTA TUJUAN TI (IT GOALS) YANG MENDUKUNG PENCAPAIANNYA

\begin{tabular}{|c|c|c|c|c|c|}
\hline Business Goals & \multicolumn{5}{|c|}{ IT Goals } \\
\hline $\begin{array}{l}\text { Improve and maintain } \\
\text { business process } \\
\text { functionality. }\end{array}$ & G6 & G7 & G11 & & \\
\hline Lower process costs. & G7 & G8 & G13 & G15 & G24 \\
\hline $\begin{array}{l}\text { Improve and maintain } \\
\text { operational and staff } \\
\text { productivity. }\end{array}$ & G7 & G8 & G11 & G13 & \\
\hline
\end{tabular}

Dari tujuan-tujuan TI dapat diperoleh prosesproses TI yang mendukung pencapaian tujuantujuan TI tersebut sebagaimana terlihat pada tabel III. Karena lingkup penelitian ini hanya tahapan perencanaan, maka tujuan-tujuan TI yang tidak memiliki proses-proses dalam domain Plan \& Organize (PO), tidak diikutsertakan dalam pembahasan selanjutnya. Dengan demikian, tujuan-tujuan TI dengan nomor G6 dan G8 pada tabel diatas tidak diikutsertakan ke dalam analisis lebih lanjut pada penelitian ini.

Pada tujuan TI nomor G13, proses perencanaan yang mendukung adalah PO6, akan tetapi proses ini tidak diikutsertakan karena bukan pendukung sasaran efisiensi bisnis. Tabel IV menunjukkan sasaran utama (primary, dengan notasi P) dan sasaran sekunder (secondary, dengan notasi $\mathrm{S}$ ) bisnis untuk proses $\mathrm{PO} 2, \mathrm{PO}$, PO5, dan PO6.
TABEL III

PROSES-PROSES TI (IT PROCESSES) YANG MENDUKUNG PENCAPAIAN TUJUAN TI (IT GOALS) PT X

\begin{tabular}{|c|c|c|c|c|c|c|}
\hline No & IT Goals & \multicolumn{5}{|c|}{ IT Processes } \\
\hline G6 & $\begin{array}{l}\text { Define how business } \\
\text { functional and control } \\
\text { requirements are translated } \\
\text { in effective and efficient } \\
\text { automated solutions }\end{array}$ & AI1 & $\mathrm{AI} 2$ & AI6 & & \\
\hline G7 & $\begin{array}{l}\text { Acquire and maintain } \\
\text { integrated and standardised } \\
\text { application systems }\end{array}$ & PO3 & $\mathrm{AI} 2$ & AI5 & & \\
\hline G8 & $\begin{array}{l}\text { Acquire and maintain an } \\
\text { integrated and standardised } \\
\text { IT infrastructure }\end{array}$ & $\mathrm{AI} 3$ & AI5 & & & \\
\hline G11 & $\begin{array}{l}\text { Ensure seamless integration } \\
\text { of applications into } \\
\text { business processes. }\end{array}$ & $\mathrm{PO} 2$ & AI4 & AI7 & & \\
\hline G13 & $\begin{array}{l}\text { Ensure proper use and } \\
\text { performance of the } \\
\text { applications and technology } \\
\text { solutions. }\end{array}$ & PO6 & AI4 & AI7 & DS7 & DS8 \\
\hline G15 & $\begin{array}{l}\text { Optimise the IT } \\
\text { infrastructure, resources } \\
\text { and capabilities. }\end{array}$ & PO3 & $\mathrm{AI} 3$ & DS3 & DS7 & DS9 \\
\hline G24 & $\begin{array}{l}\text { Improve IT's cost-efficiency } \\
\text { and its contribution to } \\
\text { business profitability. }\end{array}$ & PO5 & DS6 & & & \\
\hline
\end{tabular}

TABEL IV

SASARAN PENGENDALIAN UTAMA (P) DAN SEKUNDER (S) PROSES-PROSES PERENCANAAN PO2, PO3, PO5 DAN PO6

\begin{tabular}{|c|c|c|c|c|c|c|c|c|}
\hline 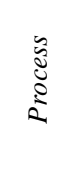 & Description & 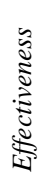 & 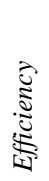 & 芯 & 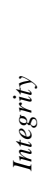 & 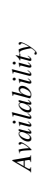 & 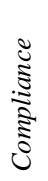 & 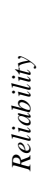 \\
\hline $\mathrm{PO} 2$ & $\begin{array}{l}\text { Define the Information } \\
\text { Architecture }\end{array}$ & $S$ & $\mathrm{P}$ & $\mathrm{S}$ & $P$ & & & \\
\hline PO3 & $\begin{array}{l}\text { Determine Technological } \\
\text { Direction }\end{array}$ & $\mathrm{P}$ & $\mathrm{P}$ & & & & & \\
\hline PO5 & Manage the IT Investment & $\mathrm{P}$ & $\mathrm{P}$ & & & & & $\mathrm{S}$ \\
\hline PO6 & $\begin{array}{l}\text { Communi-cate Manage-ment } \\
\text { Aims and Direction }\end{array}$ & $\mathrm{P}$ & & & & & $\mathrm{S}$ & \\
\hline
\end{tabular}

Pembobotan risiko integrasi dilakukan oleh para manajer di divisi TI PT X beserta atas pernyataan-pernyataan potensi risiko (risk drivers) terkait proses PO2, PO3, dan PO5 dalam dokumen COBIT Control Practices [7]. Penetapan bobot dilakukan berdasarkan tingkat kekhawatiran dengan skala 0 sampai 3 atas setiap pernyataan risiko yang ditetapkan melalui konsensus. Adapun kriteria dari tiap nilai skala tersebut adalah: 0 - Perusahaan sudah sangat yakin bahwa risiko tersebut tidak akan terjadi atau tidak ada dampaknya; 1 - Risiko tersebut kecil kemungkinannya untuk terjadi atau kecil dampaknya; 2 - Risiko tersebut mungkin untuk terjadi atau cukup besar dampaknya; dan 3 - 
Risiko tersebut sangat mungkin untuk terjadi atau sangat besar dampaknya.

TABEL V

TINGKAT (SCORE) KEKHAWATIRAN MANAJEMEN TI TERHADAP TIAP RISIKO (RISK) TERKAIT SASARAN-

SASARAN PENGENDALIAN (CONTROL OBJECTIVE) PADA PROSES PO2

\begin{tabular}{|c|c|c|c|c|c|c|}
\hline \multirow{2}{*}{$\mathrm{CO}$} & \multirow{2}{*}{ No } & \multirow{2}{*}{ Risk } & \multicolumn{4}{|c|}{ Score } \\
\hline & & & 0 & 1 & 2 & 3 \\
\hline \multirow[t]{6}{*}{ PO2.1 } & 1 & $\begin{array}{l}\text { Inadequate information for } \\
\text { business functions }\end{array}$ & & & $\sqrt{ }$ & \\
\hline & 2 & $\begin{array}{l}\text { Inconsistency between } \\
\text { information requirements and } \\
\text { application developments }\end{array}$ & & & $\sqrt{ }$ & \\
\hline & 3 & $\begin{array}{l}\text { Data inconsistency between the } \\
\text { organisation and systems }\end{array}$ & & $\sqrt{ }$ & & \\
\hline & 4 & $\begin{array}{l}\text { High effort required or inability } \\
\text { to comply with fiduciary } \\
\text { obligations (e.g, compliance } \\
\text { reporting, security, privacy) }\end{array}$ & & $\sqrt{ }$ & & \\
\hline & 5 & $\begin{array}{l}\text { Inefficient planning of IT- } \\
\text { enabled invesment programmes } \\
\text { due to lack of information }\end{array}$ & & $\sqrt{ }$ & & \\
\hline & 6 & $\begin{array}{l}\text { Accumulation of data that are } \\
\text { not relevant, consistent or } \\
\text { usable in an economical manner }\end{array}$ & $\sqrt{ }$ & & & \\
\hline \multirow[t]{3}{*}{$\mathrm{PO} 2.2$} & 1 & $\begin{array}{l}\text { Compromised information } \\
\text { integrity }\end{array}$ & $\sqrt{ }$ & & & \\
\hline & 2 & $\begin{array}{l}\text { Incompatible and inconsisten } \\
\text { data }\end{array}$ & & & $\sqrt{ }$ & \\
\hline & 3 & Ineffective application controls & & $\sqrt{ }$ & & \\
\hline \multirow[t]{5}{*}{ PO2.3 } & 1 & $\begin{array}{l}\text { Inappropriate security } \\
\text { requirements }\end{array}$ & & $\sqrt{ }$ & & \\
\hline & 2 & $\begin{array}{l}\text { Inadequate or excessive } \\
\text { invesments in security controls }\end{array}$ & & $\sqrt{ }$ & & \\
\hline & 3 & $\begin{array}{l}\text { Occurance of privacy, data, } \\
\text { confidentiality, integrity and } \\
\text { availability incidents }\end{array}$ & & $\sqrt{ }$ & & \\
\hline & 4 & $\begin{array}{l}\text { Non-compliance with regulatory } \\
\text { or third-party requirements }\end{array}$ & & $\sqrt{ }$ & & \\
\hline & 5 & $\begin{array}{l}\text { Inefficient or inconsistent } \\
\text { information for decision making }\end{array}$ & & & $\sqrt{ }$ & \\
\hline \multirow[t]{4}{*}{$\mathrm{PO} 2.4$} & 1 & $\begin{array}{l}\text { Data integrity error and } \\
\text { incuidents }\end{array}$ & & & $\sqrt{ }$ & \\
\hline & 2 & $\begin{array}{l}\text { Unreliable data on which to } \\
\text { base business decisions }\end{array}$ & & $\sqrt{ }$ & & \\
\hline & 3 & $\begin{array}{l}\text { Non-compliance with regulatory } \\
\text { or third-party requirements }\end{array}$ & & $\sqrt{ }$ & & \\
\hline & 4 & Unreliable external reports & & $\sqrt{ }$ & & \\
\hline
\end{tabular}

Tabel V menunjukkan hasil penilaian tingkat kekhawatiran terhadap konsekuensi yang mungkin dialami (risiko) terkait dengan proses COBIT dalam hal pendefinisian arsitektur informasi (PO2). Tabel VI menunjukkan hasil penilaian tingkat kekhawatiran terhadap konsekuensi yang mungkin dialami (risiko) terkait dengan proses COBIT dalam hal pemilihan arah/standar teknologi (PO3). Tabel VII menunjukkan hasil penilaian tingkat kekhawatiran terhadap konsekuensi yang mungkin dialami (risiko) terkait dengan proses COBIT dalam hal pengelolaan investasi TI (PO5).

Penilaian terhadap tingkat kemapanan ini dilakukan berdasarkan bukti-bukti yang ada. Tingkat kemapanan ini dinilai dengan menggunakan model kemapanan generik (generic maturity model) yang ada pada dokumen COBIT 4.1. Hasil penilaian tersebut disajikan pada tabel VIII.

Bobot risiko dan tingkat kemapanan suatu control objective kemudian dipetakan ke dalam suatu diagram kuadran. Sumbu vertikal pada kuadran ini adalah tingkat kemapanan pemenuhan control objective tersebut, sedangkan sumbu horizontal adalah bobot risiko atau tingkat kekhawatiran perusahaan terhadap risiko-risiko jika control objective tersebut tidak terpenuhi. Kategori dari masing-masing kuadran untuk tiap kombinasi tingkat kemapanan dan bobot risiko adalah seperti pada tabel IX.

Dari pemetaan kuadran, selanjutnya dipilih control objectives yang berada pada kuadran under controlled untuk menjadi fokus peningkatan kemampuan tata kelola TI dalam rangka integrasi SI/TI. Dari data yang ada, hanya proses PO3 yang memiliki control objectives pada kuadran under controlled, sebagaimana terlihat pada gambar 2. Perbedaan ukuran lingkaran dan warna tidak mempunyai arti tersendiri, hanya sebagai pertanda adanya tumpukan titik karena menempati koordinat yang sama.

Penyempurnaan tingkat kemapanan untuk tiap control objective yang masuk kategori under controlled dapat dilakukan dengan mengadopsi control practices yang disediakan sebagai suplemen dokumen COBIT. Tabel X menunjukkan praktik-praktik yang berhasil dalam pemenuhan control objectives di bawah proses PO3. 
TABEL VI

TINGKAT (SCORE) KEKHAWATIRAN MANAJEMEN TI

TERHADAP TIAP RISIKO (RISK) TERKAIT SASARAN-

SASARAN PENGENDALIAN (CONTROL OBJECTIVE) PADA PROSES PO3

\begin{tabular}{llllll}
\multicolumn{3}{c}{ PROSES PO3 } \\
\hline \multirow{2}{*}{ CO No } & Risk & \multicolumn{4}{c}{ Score } \\
\cline { 2 - 5 } & & 0 & 1 & 2 & 3 \\
\hline
\end{tabular}

\begin{tabular}{|c|c|}
\hline 1 & $\begin{array}{c}\text { Technological acquisitions inconsistent } \\
\text { with strategic plans }\end{array}$ \\
\hline 2 & $\begin{array}{l}\text { IT infrastructure inappropriate for } \\
\text { organisational requirements }\end{array}$ \\
\hline 3 & $\begin{array}{l}\text { Deviations from the approved } \\
\text { technological direction }\end{array}$ \\
\hline
\end{tabular}

4 Increased cost due to unco-ordinated and unstructured acquisition plans

1 Inconsistent system implementations

2 Deviations from the approved

๗․ 3 Increased cost due to unco-ordinated and

กิ 3 unstructured acquisition plans

Organisational failure to maximize the use of emerging technological

4 opprotunities to improve business and IT capability

Non-compliance with regulatory requirements

High effort required to achieve

2 compliance because of wrong or late decisions

๓่. Technical incompatibilities or

3 maintenance issues within the IT infrastructure

Organisational failure to maximize the use of emerging technological

4 opprotunities to improve business and IT capability

Incompatibilities between technology platform and applications

Deviations from the approved technological direction

\section{Licensing violations}

Increased support, replacement and maintenance cost

Inability to access historical data on unsupported technology

Incompatibilities between technology platform and applications Deviations from the approved
technological direction Uncontrolled acquisition, use and

3 possible proliferation of information system assets

TABEL VII

TINGKAT (SCORE) KEKHAWATIRAN MANAJEMEN TI TERHADAP TIAP RISIKO (RISK) TERKAIT SASARAN-SASARAN PENGENDALIAN (CONTROL OBJECTIVE) PADA PROSES PO5

\begin{tabular}{lll}
\hline $\mathrm{CO}$ No & Risk & $\frac{\text { Score }}{0123}$ \\
\hline
\end{tabular}

PO5.1 1 Unclear priorities for IT projects

2 Inefficient process for financial Management

3 IT budget not reflecting business Needs

4 Weak control over IT budgets

5 Failure of senior management to approve the IT budgets

6 Lack of senior management support $\sqrt{ }$

PO5.2 1 Inefficient resource management $\sqrt{ }$

2 Inability to optimise goals and Objectives

3 Confusion, demotivation and loss of agility due to unclear priorities

4 IT budget not in line with the IT strategy and investment decisions

PO5.3 1 Resource conflicts

2 Inappropriate allocation of financial resources of IT operations

3 Financial resources not aligned with the organisation's goals

4 Lack of empowerment, leading to loss of agility 5 Lack of senior management support
for the IT budget

PO5.4 1 Misspending of IT investments

2 Inappropriate service pricing

3 IT value contribution not transparent $\sqrt{ }$

PO5.5 1 Misspending of IT investments $\quad \sqrt{ }$

2 Inappropriate service pricing $\quad \sqrt{ }$

3 IT value contribution not transparent $\sqrt{ }$

$4 \begin{aligned} & \text { Incorrect perception of IT value } \\ & \text { Contribution }\end{aligned}$ 
30 Journal of Information Systems, Volume 5, Issues 1, April 2009

TABEL VIII

TINGKAT KEMAPANAN SASARAN-SASARAN PENGENDALIAN TERKAIT PROSES-PROSES PO2, PO3 DAN PO5

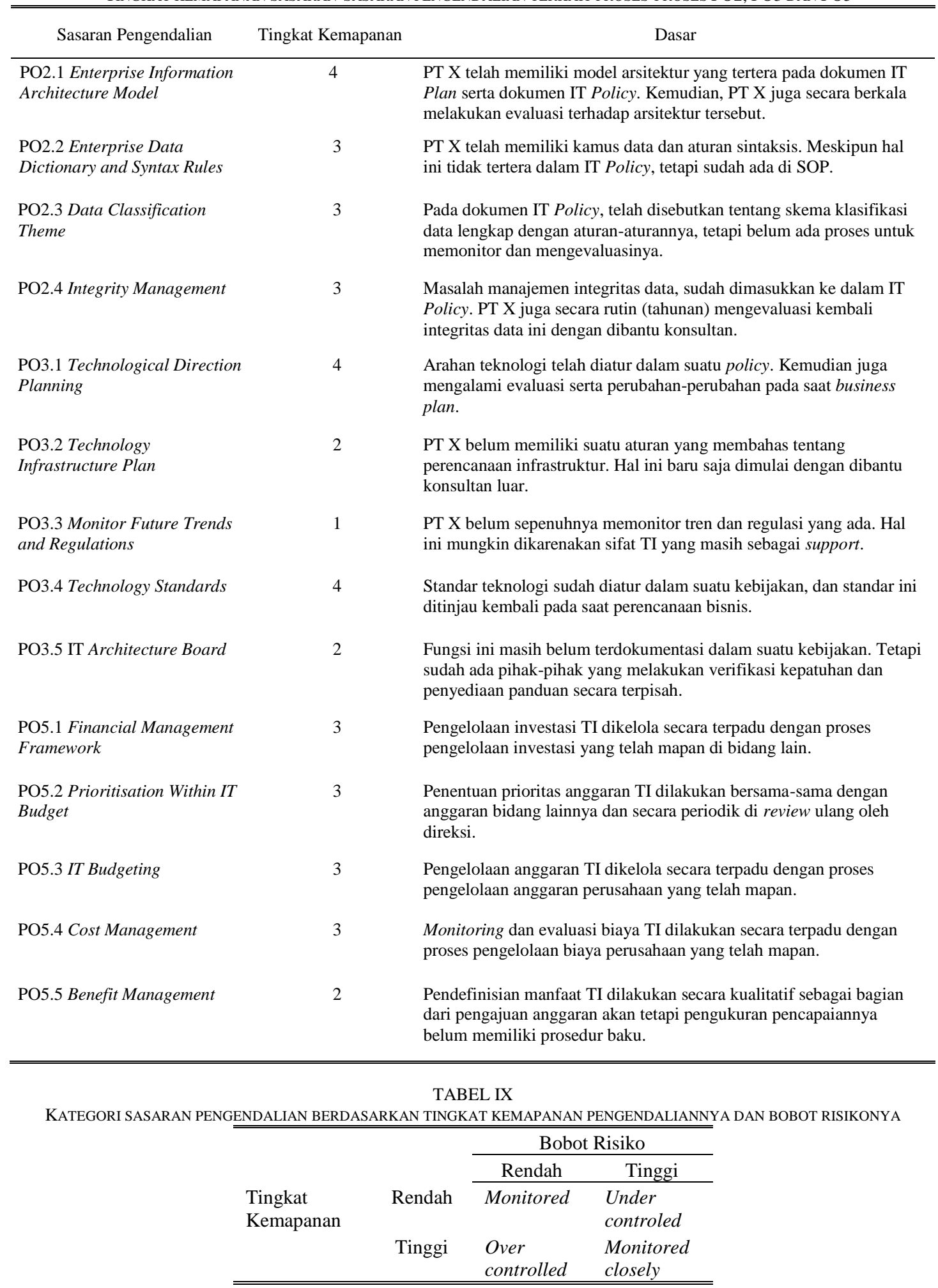


TABEL X

TEKNIK PENGENDALIAN (CONTROL PRACTICES) UMUM UNTUK MEREALISASIKAN SASARAN-SASARAN PENGENDALIAN (CONTROL OBJECTIVES) DALAM PROSES PENENTUAN ARAH/KEBIJAKAN PEMILIHAN TEKNOLOGI (PO3)

\begin{tabular}{cl}
\hline Control & \multicolumn{1}{c}{ Control Practices } \\
Objectives & \\
\hline PO3.2-3 & $\begin{array}{l}\text { Include transitional and other costs, } \\
\text { complexity, technical risks, future } \\
\text { flexibility, value, and product/vendor } \\
\text { sustainability in the technology } \\
\text { infrastructure plan. } \\
\text { Ensure that adequately skilled staff } \\
\text { members within the IT department } \\
\text { routinely monitor technological } \\
\text { developments, competitor activities, } \\
\text { infrastructure issues, legal requirements } \\
\text { and regulatory environment changes, and } \\
\text { provide relevant information to senior } \\
\text { management. Consult third-party experts } \\
\text { to obtain views and confirm findings and } \\
\text { proposals of internal staff. } \\
\text { Ensure that the organisation's legal } \\
\text { counsel monitors legal and regulatory } \\
\text { conditions in all relevant locations and } \\
\text { informs the IT steering committee of any } \\
\text { changes that may impact the technology } \\
\text { infrastructure plan. } \\
\text { Evaluate new technologies in the context } \\
\text { of their potential contribution to the } \\
\text { realisation of broader business goals and } \\
\text { targets using established criteria, e.g., } \\
\text { ROI, or ability to achieve market } \\
\text { leadership. }\end{array}$ \\
\hline \hline &
\end{tabular}

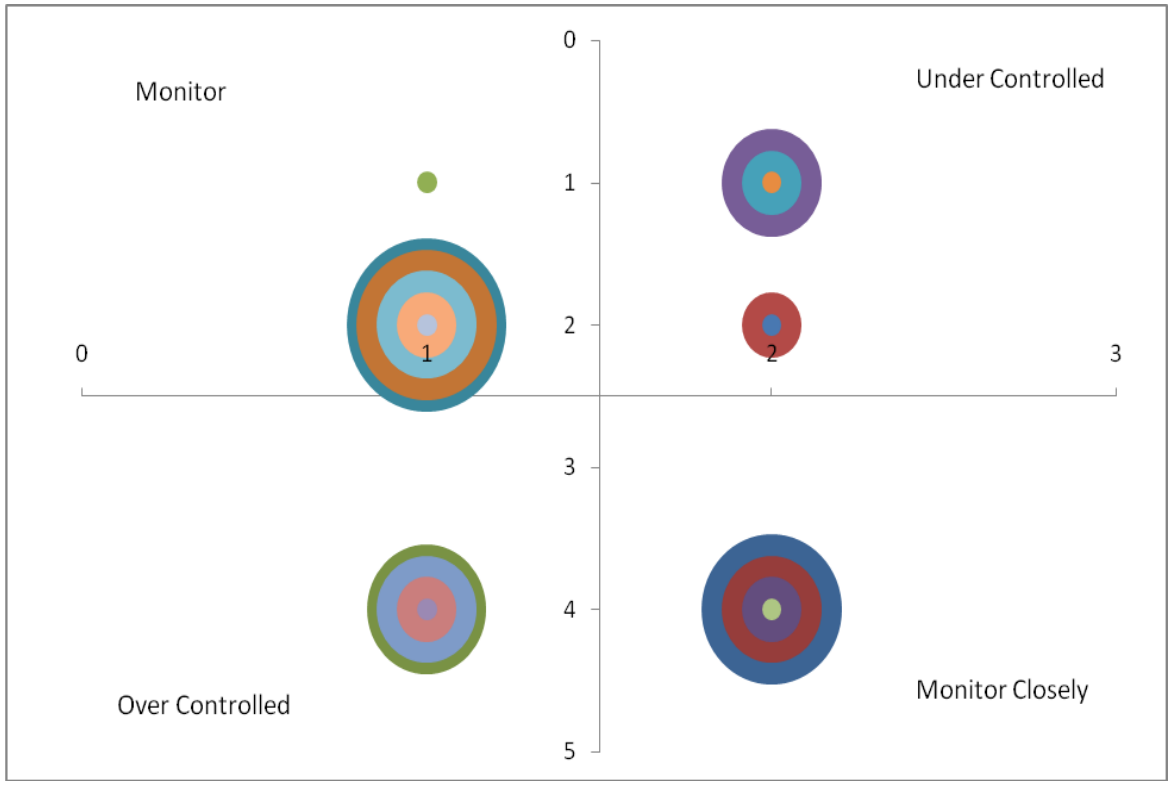

Gambar 2. Kuadran prioritas untuk proses penentuan arah/kebijakan pemilihan teknologi (PO3).

Acuan di atas diberikan kepada pihak terkait untuk diidentifikasi hal-hal yang menjadi penghambat dan pendukung. Hal ini dilakukan dengan memberikan suatu formulir isian kepada para manajer di bawah divisi TI.

PO3.2-3: Unsur biaya-biaya transisi, kompleksitas, risiko teknis, fleksibilitas di masa depan, dan sustainability dari vendor cukup berpeluang untuk dimasukkan dalam perencanaan infrastruktur. Hal ini dikarenakan bahwa di PT X, telah ada proses assessment terhadap aspek-aspek tersebut, sehingga tidaklah menjadi hal yang sulit 
bagi PT X dalam menerapkan teknik pengendalian ini. Adapun hal yang masih menjadi tantangan bagi perusahaan adalah bahwa perencanaan infrastruktur masih dalam proses pembuatan, sehingga PT X bisa dikatakan belum mempunyai pengalaman dalam hal ini.

PO3.3-2: Terhadap teknik pengendalian ini, PT X cukup berpeluang untuk melakukannya. Dengan adanya merger, maka PT X banyak memiliki kompetensi yang dapat mendukung terlaksananya hal tersebut. PT X telah melakukan pemetaan atas kebutuhan tersebut. Namun tantangannya saat ini adalah bahwa, tidak semua item-item, yang seharusnya dimonitor, akan terlaksana. Hal ini dikarenakan bahwa kompetensi yang ada didapat dari hasil kebutuhan masa lampau (sebelum merger).

PO3.3-3: PT X sebenarnya memiliki peluang yang besar untuk dapat melakukan teknik pengendalian ini. Hal ini dikarenakan PT X telah memiliki suatu komite audit tersendiri yang tugasnya melakukan audit terhadap permasalahan TI. Audit ini dilakukan secara rutin, dan hasilnya dilaporkan ke Komite Audit perusahaan. Namun, yang masih menjadi tantangan saat ini adalah bahwa PT $X$ belum memiliki perencanaan infrastruktur. Perencanaan tersebut saat ini masih dalam proses.

PO3.2-4: Untuk teknik pengendalian ini, meskipun PT $\mathrm{X}$ telah menyadari bahwa hal tersebut memang penting, namun hal ini tidak terlalu berpeluang untuk dilaksanakan. Hal ini dikarenakan PT X belum memiliki tools yang tepat, sumber daya manusia dan aspek teknis lainnya dalam mengukur kontribusi TI terhadap perusahaan. Selain itu, kemampuan ini juga sulit diraih dalam waktu dekat karena PT X masih disibukkan dengan pengelolaan TI pasca merger.

\section{Kesimpulan}

Dengan menggunakan pendekatan berbasis COBIT, telah teridentifikasi kebutuhan akan adanya mekanisme tata kelola TI terkait penetapan arah/kebijakan pemilihan teknologi bagi keberhasilan usaha penyatuan SI/TI lintas anak perusahaan di PT X. Dari hasil evaluasi atas kondisi tata kelola TI PT X, secara umum dapat disimpulkan bahwa integrasi SI/TI bagi PT X tidak akan banyak menghadapi konflik, terutama karena induk perusahaan telah sebelumnya mewajibkan penggunaan suatu aplikasi berskala enterprise.

\section{Referensi}

[1] IT Governance Institute, Board Briefing on IT Governance, 2nd ed., 2003.

[2] IT Governance Institute, COBIT 4.1: Control Objectives, Management Guidelines, Maturity Models, 2007.

[3] W. Van Grambergen \& S. DeHaes, Implementing Information Technology Governance, IGI Global, 2005.

[4] Carnegie Mellon Software Engineering Institute [SEI], CMMI for Development, Version 1.2, CMU/SEI-2006-TR-008 ESCTR-2006-008, 2006.

[5] M. Pareek, "IT Governance and Postmerger Systems Integration," Information Systems Control Journal, vol. 2, 2005.

[6] M. Bhatia, "IT Merger Due Diligence: a Blueprint," Information Systems Control Journal, vol. 3, 2004.

[7] IT Governance Institute, COBIT Control Practices: Guidance to Achieve Control Objectives for Successful IT Governance, 2nd Ed., 2007. 